\title{
Analisis Pelaksanaan Corporate Social Responsibility Pada Perbankan Syariah Dalam Prespektif Shariah Enterprise Theory (Studi Kasus Pada Laporan Tahunan PT Bank Syariah Mandiri Tahun 2015 di Bursa Efek Indonesia)
}

\author{
NURHAYANI LUBIS ${ }^{1}$; HARDI $^{2}$; AZNURIYANDI; INTAN FRADILA ${ }^{4}$ \\ Universitas Lancang Kuning \\ Jln. Yos Sudarso Km 08 Rumbai Telp. (0761) 52581 Fax. (0761) 52581 \\ E-mail : nurhayanilubis.ani@gmail.com
}

\begin{abstract}
This research was conducted to describe and analyze the implementation of how much Corporate Social Responsibility is in Mandiri Syariah Banking in Pekanbaru. This study uses descriptive qualitative research method using Bank Syariah Mandiri annual report data in 2015. To analyze the data properly, accurate, reliable and systematic data is needed so that the results obtained can describe objects that are being researched correctly through literature study on Shariah Enterprise Theory and field studies in the form of in depth interviews. The results show that Bank Mandiri Syariah in 2015 has implemented Corporate Social Responsibility well, in terms of the Shariah Enterprise Theory it can be seen that Bank Mandiri Syariah is committed to carrying out its social responsibility well.
\end{abstract}

Keywords: CSR, Islamic Bank, Shariah Enterprise Theory

Sebagai salah satu lembaga yang tumbuh dan berkembang di Indonesia, lembaga perbankan memiliki tanggung jawab terhadap lingkungan di sekitar perusahaan perbankan tersebut beroperasi. Tanggung jawab tersebut dikenal dengan istilah "Tanggung Jawab Sosial Perusahaan atau Corporate Social Responsibility (CSR)". Penggunaan istilah Tanggung Jawab Sosial Perusahaan atau Corporate Social Responsibility (CSR) akhir-akhir ini sangat popular dengan semakin meningkatnya praktek tanggung jawab sosial perusahaan, dan diskusi-diskusi global, regional dan nasional tentang CSR (Hardiansyah: 2008). Hal tersebut sebenarnya telah di atur dalam UU No.40/2007 yang menyebutkan, Tanggung Jawab Sosial dan Lingkungan adalah komitmen Perseroan untuk berperan serta dalam pembangunan ekonomi berkelanjutan guna meningkatkan kualitas kehidupan dan lingkungan yang bermanfaat, baik bagi Perseroan sendiri, komunitas setempat, maupun masyarakat pada umumnya.
Tanggung jawab sosial ini juga dimiliki oleh perusahaan BUMN, dimana perusahaan BUMN ini memilili banyak sektordan salah satunya adalah sektor perbankan, dan PT Bank Syariah Mandiri merupakn salah satunya. Selain landasan hukum tersebut, perusahaan juga memiliki kewajiban dalam menjaga nama baik dan citra perusahaan di masyarakat. Oleh karena itu, perusahaan wajib melakukan CSR sebagai salah satu wujud tantangan dalam menghadapi pesaing-pesaing yang juga melakukan CSR untuk menjaga citra perusahaannya di masyarakat. Salah satu jenis bank yang memainka peranan penting dalam tanggungjawab sosial adalah bank syariah.

Penelitian tentang bank syariah ini sangat menarik untuk dilakukan, karena bank syariah merupakan bank yang dapat bertahan di setiap kondisi perekonomian dan bank syariah telah terdapat di hampir seluruh negara. Di Indonesia, pendirian bank syariah dilakukan setelah diterbitkannya UU Perbankan no. 7 tahun 
1992 yang memungkinkan bank untuk memperoleh pendapatan dari bagi hasil, selain dari bunga. Perbankan syariah di Indonesia menunjukkan pertumbuhan yang tinggi, telah menjalankan fungsi intermediasi secara sehat dan operasi perbankan secara hati-hati (Bank Indonesia, 2013; Ismal \& Haryati, 2013). Selanjutnya dalam UU Perbankan no. 21 tahun 2008 dinyatakan bahwa disamping menjalankan fungsi intermediasi, perbankan syariah dapat melakukan fungsi sosial.

Selain itu, bank syariah diharapkan memiliki dimensi yang berfokus pada spiritual. Yang di dalam agama islam, apabila di bidang oerbankan, dimensi tersebut adalah bisnis non riba yang dapat di jalankan sesuai syariat islam dan dapat memebrikan kesejahteraan bagi masyarakat, dan di utamakan masyarakat dari golongan ekonomi lemah. Dan perbankan syariah diharapkan seharusnya dapat menjadi percontohan dalam menggerakkan program CSR. Pelaksanaan CSR oleh perbankan syariah diharapkan bukan hanya memenuhi tanggung jawab yang telah di tetapkan, tetapi lebih dlaam lagi bahwa perbankan syariah dalam menjalankan tanggung jawab sosialnya di di bangun di atas fondasi agama islam yang kuat yang sesuai syariat islam dan mempunyai tujuan mensejahterakan masyarakat.

\section{Corporate Social Responsibility} (CSR) juga dapat diartikan sebagai tanggung jawab para pemangku kepentingan untuk bersikap etis, mengurangi dampak negatif, dan mengusahakan seoptimalnya dampat postif bagi perusahaan yang di sesuaikan dengan visid an misi perusahaan, dapat dilakukan secara terus menerus dan tujuan akhirnya adalah pembangunan berkelanjutan dan baik dari segi sosial, ekonomi, dan budaya.

Kotler dan Lee (2005) dalam (Solihin: 2009) memberikan rumusan: "corporate social responsibility is a commitment to improve community well being through discretionary business practices and contribution of corporate resources"

Dalam definisi tersebut, Kotler dan Lee memberikan penekanan pada kata discretionary yang berarti kegiatan CSR semata-mata merupakan komitmen perusahaan secara sukarela untuk turut meningkatkan kesejahteraan komunitas dan bukan meruapakan aktifitas bisnis yang diwajibkan oleh hukum dan perundangundangan seperti kewajiban untuk membayar pajak atau kepatuhan perusahaan terhadap undang-undang ketenagakerjaan. Kata discretionary juga memberikan nuansa bahwa perushaan yang melakukan aktivitas CSR haruslah perusahaan yang telah menaati hukum dalam pelaksaaan bisnisnya. (Solihin 2009). Menurut Undang-undang Perseroan Terbatas No.40 tahun 2007 pasal 1 ayat 3. Tanggung Jawab Sosial dan Lingkungan adalah komitmen Perseroan untuk berperan serta dalam pembangunan ekonomi berkelanjutan guna meningkatkan kualitas kehidupan dan lingkungan yang bermanfaat, baik bagi Perseroan sendiri, komunitas setempat, maupun masyarakat pada umumnya.

Menurut (Prastowo dan Huda 2011): CSR adalah mekanisme alami sebuah perusahaan untuk membersikan keuntungan-keuntungan besar yang diperoleh. Sebagaimana diketahui, caracara perusahaan untuk memperolah keuntungan kadang-kadang merugikan orang lain, baik itu yang tidak disengaja apalagi yang disengaja. Dikatakan sebagai mekanisme alamiah karena CSR adalah konsekuensi dari dampak keputusan keputusan ataupun kegiatan-kegiatan yang dibuat oleh perusahaan, maka kewajiban perusahaan tersebut adalah membalikkan keadaan masyarakat yang mengalami dampak tersebut kepada keadaan yang lebih baik. 6. Definisi menurut ISO 26000 dalam (Prastowo dan Huda 2011) adalah: "Responsibility of organization for the impacts of its decisions and activities on 
332 Analisis Pelaksanaan Corporate Social Responsibility Pada Perbankan Syariah Dalam Prespektif Shariah Enterprise Theory (Studi Kasus Pada Laporan Tahunan PT Bank Syariah Mandiri Tahun 2015 di

Bursa Efek Indonesia)

(Nurhayani Lubis, Hardi, Aznuriyandi)

society and the environment, through transparent and ethical behavior that contributes to sustainable development, including health and the welfare of society; takes into account the expectations of stakeholders; is in compliance with applicable law and consistent with international norms of behavior; and is integrated throughout the organization and practiced in its relationship."

Terjemahan bebasnya: (Tanggung jawab sebuah organisasi terhadap dampakdampak dari keputusan-keputusan dan kegiatan-kegiatanya pada masyarakat dan lingkungan yang diwujudkan dalam bentuk perilaku transparan dan etis yang sejalan dengan pembangunan berkelanjutan termasuk kesehatan 10 dan kesejahteraan masyarakat; mempertimbangkan harapan pemangku kepentingan; sejalan dengan hukum yang ditetapkan dengan normanorma perilaku internasional; serta terintegrasi dengan organisasi secara menyeluruh) (Prastowo dan Huda 2011).

Meutia (2010) berpendapat bahwa teori yang paling tepat untuk mengungkapkan CSR, dalam hal ini bank syariah, adalah shariah enterprise theory. Hal ini karena dalam shariah enterprise theory, Allah adalah sumber amanah utama. Sedangkan sumber daya yang dimiliki para stakeholders adalah amanah dari Allah yang di dalamnya melekat sebuah tanggung jawab untuk menggunakan dengan cara dan tujuan yang ditetapkan oleh Sang Maha Pemberi Amanah. Shariah enterprise theory mengajukan beberapa konsep terkait dengan pengungkapan tanggung jawab sosial sebuah perusahaan, terutama pada perbankan syariah. Konsep-konsep tersebut, dijelaskan Meutia (2010), adalah :

1. Pengungkapan tanggung jawab sosial merupakan bentuk akuntabilitas manusia terhadap Tuhan dan karenanya ditujukan untuk mendapatkan ridho (legitimasi) dari Tuhan sebagai tujuan utama.

2. Pengungkapan tanggung jawab sosial harus memiliki tujuan sebagai sarana pemberian informasi kepada seluruh stakeholders (direct, in-direct, dan alam) mengenai seberapa jauh institusi tersebut telah memenuhi kewajiban terhadap seluruh stakeholders.

3. Pengungkapan tanggung jawab sosial adalah wajib (mandatory), dipandang dari fungsi bank syariah sebagai salah satu instrumen untuk mewujudkan tujuan syariah.

4. Pengungkapan tanggung jawab sosial harus memuat dimensi material maupun spriritual berkaitan dengan kepentingan para stakeholders. Pengungkapan tanggung jawab sosial harus berisikan tidak hanya informasi yang bersifat kualitatif, tetapi juga informasi yang bersifat kuantitatif. Selain itu, shariah enterprise theory mengajukan beberapa karakteristik terkait tema dan item yang diungkapkan dalam laporan tanggung jawab sosial perusahaan perbankan syariah.

Karakteristik-karakteristik ini, menurut Meutia (2010), adalah:

1. Menunjukkan upaya memenuhi akuntabilitas vertikal terhadap Tuhan dan akuntabilitas horizontal terhadap direct stakeholders, indirect stakeholders, dan alam.

2. Menunjukkan upaya memenuhi kebutuhan material dan spiritual seluruh stakeholders, sebagai bagian dari upaya untuk memenuhi konsep keseimbangan.

3. Mengungkapkan informasi kualitatif dam kuantitatif sebagai upaya untuk memberikan 
informasi yang lengkap dan menyeluruh.

Meutia (2010) mengatakan terdapat beberapa dimensi yang ditawarkan oleh shariah enterprise theory dalam pengungkapan tanggung jawab sosial perusahaan, terutama oleh perbankan syariah. Dimensi-dimensi tersebut adalah akuntabilitas vertikal dan akuntabilitas horizontal. Akuntabilitas vertikal ini, ditujukan hanya kepada Tuhan. Sedangkan akuntabilitas horizontal, ditujukan kepada tiga pihak, yaitu direct stakeholders, indirect stakeholders, dan alam. Pihakpihak yang disebut direct stakeholders menurut shariah enterprise theory adalah nasabah dan karyawan. Sedangkan pihak yang termasuk indirect stakeholders menurut shariah enterprise theory adalah komunitas.

\section{METODE}

Penelitian ini menggunakan metode kualitatif deskriptif. Penelitian kualitatif adalah penelitian yang menekankan pada kualitas atau hal yang terpenting dari sifat suatu barang atau jasa. Suatu penelitian kualitatif dieksplorasi dan diperdalam dari suatu fenomena sosial atau suatu lingkungan sosial yang terdiri atas pelaku, kejadian, tempat dan waktu. Fenomena yang diusung dalam penelitian kualitatif menjadi bahan baru dan hasil penelitiannya memiliki kontribusi terhadap teori (Yin, 2009). Berdasarkan karakteristik masalah yang diusung dalam penelitian ini, pendekatan penelitian yang digunakan adalah deskriptif kualitatif yang bertujuan untuk mengetahui dan memahami tentang pelaksanaan CSR pada perbankan syariah apakah sesuai dengan konsep Shariah Enterprise Theory (SET). Jenis dan sumber data Sumber data yang digunakan dalam penelitian mengenai pelaksanaan CSR ini diperoleh melalui data sekunder. Data sekunder mengacu pada informasi yang dikumpulkan pada sumber yang telah ada. Data yang dapat diperoleh dari data sekunder meliputi dokumentasi

perusahaan, publikasi pemerintah, analisis industri oleh media, situs web dan internet.

Data sekunder yang dimaksud dalam penelitian ini adalah Corporate Social Responsibility Report milik Bank Mandiri Syraiah terkait yang diperoleh melalui situs resmi yaitu www.syariahmandiri.co.id serta program-program yang ada pada Laporan Tahunan (Annual Report) Bank Mandiri Syariah.

\section{HASIL}

Hasil penelitian menunjukkan bahwa Bank Syariah Mandiri telah menjalankan tanggung jawab sosialnya atau Corporate Social Responsibilitydengan baik. Hal ini tercermin dari laporan keuangan yang di publikasikan oleh Bank Syariah Mandiri. Tercermin bahwa untuk konsep Shariah Enterprise Theory, Bank Syariah Mandiri melaksanakannya dengan baik, dilihat dari pembiayaan Murabahah, Mudharabah, Musyarakah.

\section{PEMBAHASAN}

Akuntabilitas Vertikal, yaitu kepada Allah SWT, Pengungkapan tanggung jawab sosial merupakan bentuk akuntabilitas manusia terhadap Tuhan dan karenanya ditujukan untuk mendapatkan ridho (legitimasi) dari Tuhan sebagai tujuan utama.

Triyuwono (2006) pernah menjelaskan bahwa akuntabilitas terhadap Allah dapat dilihat dari kepatuhan terhadap opini Dewan Pengawas Syariah. Laporan Dewan Pengawas Syariah dalam hal ini memberikan jaminan bahwa operasional dan produk bank syariah telah sesuai dengan fatwa Dewan Syariah Nasiona (DS Majelis Ulama Indonesia, dan Opini DPS. Di lihat dari pengertian diatas maka BSM dalam hal ini dapat dikatakan telah memenuhi akuntabilitas terhadap Allah melalui keberadaan opini Dewan Pengawas Syariah (DPS) dalam laporan tahunannya.

Terhadap perekonomian dan lingkungan 
334 Analisis Pelaksanaan Corporate Social Responsibility Pada Perbankan Syariah Dalam Prespektif Shariah Enterprise Theory (Studi Kasus Pada Laporan Tahunan PT Bank Syariah Mandiri Tahun 2015 di

Bursa Efek Indonesia)

(Nurhayani Lubis, Hardi, Aznuriyandi)

Pengungkapan tanggung jawab sosial harus memiliki tujuan sebagai sarana pemberian informasi kepada seluruh stakeholders (direct, in-direct, dan alam) mengenai seberapa jauh institusi tersebut telah memenuhi kewajiban terhadap seluruh stakeholders. Dalam mengimplementasikan tata kelola risiko, BSM menerapkan pendekatan Enterprise Risk Management (ERM). Penerapan ERM akan memberikan nilai tambah (value added) bagi Bank dan stakeholders terutama dikaitkan dengan pelaksanaan penilaian kinerja berbasis risiko (Risk Based Performance). Mengembangkan kebijakan Business Continuity Management (BCM) untuk menjamin kegiatan operasional Bank tetap dapat berfungsi walaupun terdapat gangguan (disaster) guna melindungi kepentingan stakeholders.

Bagi BSM, pelaksanaan tanggung jawab sosial merupakan investasi sosial dalam mewujudkan pertumbuhan kinerja Bank melalui sinergi dengan stakeholders seperti pemerintah, lembaga swadaya masyarakat (LSM), organisasi massa (ormas), dan lain-lain. Dalam implementasi pelaksanaan CSR, BSM menjalin kerjasama dengan Laznas BSM / lembaga mitra dalam penyaluran dana zakat perusahaan dan pelaksanaan program-program yang bersifat kemanusiaan (humanity). Acuan kerja pelaksanaan program CSR melalui Perjanjian Kerja Sama (PKS) BSM dan Laznas BSM No. 12/410- PKS/DIR; No. 09/001/LAZBSM/DIR tanggal 12 November 2010 tentang Penyaluran Zakat dan Dana Program.

Untuk memastikan pencapaian tujuan strategis pelaksanaan program tanggung jawab sosial perusahaan tersebut, BSM senantiasa mengembangkan program dengan mempertimbangkan dampak positif bagi seluruh pemangku kepentingan dan berlanjutnya manfaat pelaksanaan program bagi tumbuh dan berkembangnya kemandirian komunitas sekitar. Melalui pendekatan triplle bottom lines yang meliputi kinerja ekonomi (economic indicators), kinerja lingkungan (environmental indicators), dan kinerja sosial (social indicators), diharapkan keberadaan BSM tidak hanya bermanfaat bagi para pemegang saham (stareholders), tetapi juga kepada pemangku kepentingan (stakeholders) yang lebih luas yaitu nasabah/ konsumen, masyarakat, dan lingkungan. Dengan kata lain, BSM berusaha untuk memaksimalkan laba perusahaan (profit) selaras dengan tujuan untuk memberikan kemanfaatan yang sebesar-besarnya bagi masyarakat, dan lingkungan.

Bank Syariah Mandiri menyakini implementasi CSR akan memberikan banyak manfaat bagi BSM. Keberhasilan implementasi CSR dalam jangka panjang diyakini berpengaruh, terutama pada aspek tumbuhnya kepercayaan, terciptanya keharmonisan dan meningkatkan reputasi yang pada gilirannya memiliki implikasi pada penciptaan nilai tambah yang mendorong kelancaran kestabilan dan pertumbuhan usaha perusahaan. Salah satu pilah konsep CSR BSM adalah kesejahteraan (Economic Empowerment). Pilar konsep CSR ini diimplementasikan dalam bentuk pembinaan dan pengembangan ekonomi masyarakat melalui bantuan modal, peningkatan kompetensi, dan membangkitkan jiwa wirausaha. Contoh: BSM-isasi Kawasan Kuliner, bantuan pelatihan dan permodalan pengusaha kecil, dan lain-lain. Hal ini merupakan pelaksanaan dari visi BSM, yaitu suatu tujuan atau sasaran yang ingin dicapai. Visi dari Bank Syariah Mandiri adalah "Menjadi Bank Syariah Terpercaya Pilihan Mitra Usaha", Sedangkan misi BSM adalah cara untuk mencapai visi itu sendiri. Sehingga untuk menjadi Bank Syariah terpercaya pilihan mitra usaha, Bank Syariah Mandiri memiliki misi berikut ini:

a. Mewujudkan pertumbuhan dan keuntungan yang berkesinambungan. 
b. Mengutamakan penghimpunan dana konsumer dan penyaluran pembiayaan pada segmen UMKM.

c. Merekrut dan mengembangkan pegawai profesional dalam lingkungan kerja yang sehat.

d. Mengembangkan nilai-nilai syariah universal.

e. Menyelenggarakan operasional bank sesuai standar perbankan yang sehat.

BSM sebagai entitas bisnis perbankan harus memiliki kontribusi dalam pembangunan ekonomi berkelanjutan dengan membantu meningkatkan dan memberdayakan masyarakat menjadi komunitas yang mandiri secara ekonomi. Oleh karena itu, BSM cabang Pekanbaru membina hubungan yang kondusif dengan masyarakat sekitar wilayah operasionalnya, BSM merealisasikan berbagai kegiatan pengembangan potensi ekonomi masyarakat dengan satu tujuan, meningkatkan kemampuan unit-unit Usaha Kecil dan Menengah (UKM) agar mampu tumbuh dan berkembang menjadi usaha yang tangguh dan mandiri.

Selain itu, BSM merealisasikan program pengembangan komunitas melalui Program Mitra Umat bekerjasama dengan LAZNAS BSM. Program Mitra Umat, merupakan program pengembangan kemasyarakatan sekitar daerah operasional Bank, dengan tujuan akhir meningkatkan kesejahteraan masyarakat dan mengangkat perekonomian bangsa.

Selama tahun 2015, BSM telah melaksankan Program Mitra Umat dalam rangka pemberdayaan ekonomi masyarakat dengan total alokasi dana yang terdistribusikan sebesar Rp 4,01 miliar. Jumlah penerima dana Program Mitra Umat sebanyak 1.573 orang dan 42 lembaga.

\section{SIMPULAN}

Bahwa pelaksanaan Corporate Social Responsibility berdasarkan Shariah Enterprise Theory di Bank Syariah mandiri sudah dilaksanakan dengan baik.
Pelaksanaan sudah mencakup banyak hal dan bidang sesuai dengan visi dan misi Bank Syariah mandiri dan tujuan perbankan yang berbasis syariah.

\section{DAFTAR RUJUKAN}

Achua, Joseph K. 2008. Corporate Social Responsibility in Nigerian Banking System". Society and Business Review, Vol. 3 Iss: 1, pp.57- 71.

Deegan, C. and Gordon B. 1996. A Study of the Environmental Disclosure Practices of Australian Corporations. Accounting and Business Researclt. Vol. 26, No. 3, (Summer), pp. 187-99.

Dusuki, Asyraf Wajidi and Humayon Dar. 2005. Stakeholders Perceptions of Corporate Social Responsibility of Islamic Banks: Evidence from Malaysian Economy. The 6th International Confrence on Islamic Economic and Finance.

Farook, Sayd and Lanis, Roman. 2005. Banking on Islam? Determinants of Corporate Social Responsibility Disclosure". The 6th International Confrence on Islamic Economic and Finance.

Gray, R., Kouhy, R., Lavers, S. 1995 Corporate Social and Environmental Reporting: A Review of the Literature and a Longitudinal Study of UK, Disclosure, Accounting, Auditing and Accountability Journal,Vol. 8, No. 2, pp. 47-77.

Meutia, Inten. 2010. Menata Pengungkapan CSR di Bank Islam (Suatu Pendekatan Kritis). Jakarta: Citra Pustaka Indonesia. 
Cholid Narbuko dan H. Abu Achmadi. 2007. Metodologi Penelitian. Jakarta: Bumi Aksara.

Patten, D.M. 1992. Intra-industry Environmental Disclosures in Response to the Alaskan Oil Spill: A Note on Legitimacy Theory. Accounting, Organizations and Society, Vol. 15, No. 5, pp. 471-75.

Prastowo, Joko \& Huda, Miftahul. 2011. Corporate Social Responsibility, Kunci Meraih Kemuliaan Bisnis. Yogyakarta: Samudera Biru.

Sugiono. 2013. Metode Penelitian Pendidikan Pendekatan Kuantitatif, Kualitatif, dan R\&D. Bandung. Alfabeta

Solihin, Ismail. 2009. Corporate Social Responsibility from Charity to Sustainability. Jakarta : Salemba Empat.

Undang-Undang Republik Indonesia Nomor 10 Tahun 1998 tentang Perubahan atas Undang-Undang Nomor 7 Tahun 1992 tentang Perbankan. 1998. Jakarta: Departemen Hukum dan HAM.

Undang-Undang Republik Indonesia Nomor 40 Tahun 2007 tentang Perseroan Terbatas. 2005. Jakarta: Departemen Hukum dan HAM.

Yin, Robert K.2011. Studi Kasus: Desain dan Metode. Jakarta: PT.Raja grafindo Persada

Yusuf, Yasir. 2010. Aplikasi CSR pada Bank Syariah: Suatu Pendekatan Maslahah dan Maqasid syariah. EKSIBISI, Vol 4, No 2.

Yusuf, Yasir.. 2010. Aplikasi CSR pada Bank Syariah: Suatu Pendekatan
Maslahah dan Maqasid syariah. EKSIBISI, Vol 4, No 2.

Zappi, Gianna. 2007. Corporate Responsibility in the Italian banking industry: Creating Value Through Listening to Stakeholders. Corporate Governance, Vol. 7 Issue: 4, pp.471 - 475. 